\title{
Operational Research on Design and Process Optimization of Ozone Water Application in Kitchen
}

\author{
Zhun Jing Lee ${ }^{1,}$, Pui May Chou, ${ }^{1, *}$, Choon Lih $\mathrm{Hoo}^{1}$, Daniel Lu ${ }^{1}$ \\ ${ }^{1}$ School of Engineering, Taylor's University, 47500 Subang Jaya, Selangor, Malaysia
}

\begin{abstract}
Food safety is a very important focus in the kitchen industry today, as bacteria such as E.Coli and Salmonella are very difficult to tackle. The objective of the present study was to optimize nozzle designs that use ozone technology to bring out the best results in cleaning and sterilizing the kitchen utensils in Taylor's University School of Hospitality kitchen area. This includes customization of the Medklinn International Sdn Bhd ozone machine and nozzle profiles that improve the effectiveness of ozone generated. Reduction or elimination of chemicals and water usage would be a part of the study. This will bring a huge impact on cost effectiveness, time saving and safety of the users. Return on investment (ROI) using ozone technology is calculated at the end of the research. To compare between the traditional way of cleaning and using ozone technology, the volume of water and dishwashing liquid used, and the Relative Light Units (RLU) before and after washing were recorded. The RLU numbers are found using the $3 \mathrm{M}$ Clean Trace measuring equipment. RLU was recorded to determine the cleanliness of the kitchen utensils before and after washing. It has been proved that ozone water with the accompaniment of the selected nozzle prototype is as efficient as the traditional way of cleaning.
\end{abstract}

\section{Introduction}

The cleanliness of kitchen area, utensils and stoves is essential in the food processing industry. Diarrhea is a concerning issue for travelers as 1 out 3 people will be affected in this health issue. Hikers and people who go on adventure trips are very prone to this problem[1]. In 2015, World Health Organization (WHO) has estimated that 1 in 10 people are prone to foodborne diseases which also killed 420,000 people[2]. It was also reported that Africa and South East Asia are the two regions that are in the high risk zone[2]. There were 125,000 of children under five years old are killed due to illness from foodborne diseases every year [2]. It was found out that $16 \%$ of the foodborne diseases outbreaks from England and Wales are linked with the food preparation in the house [3, 4].

* Corresponding author: PuiMay.Chou@taylors.edu.my 
Cross contamination is one of the reason to the foodborne disease and it caused 28 out of 101 outbreaks to happen [3]. Cross contamination can happen either by hand to the plates, from the plates to the food, the utensils to the food, or even in the washing process with the usage of sponge and water $[3,5,6,7]$. In order to reduce and eliminate this issue, different washing up systems have been created. Researchers believe that rather than tackling the cleanliness of water, the cleanliness of kitchen utensils and hand hygiene are two very important factors to prevent foodborne diseases[1, 8]. Cross contaminations on food happens very often in the process of cutting, trimming, rinsing and washing [8]. Bacteria infect almost all the kitchen area, as study shown in appendix 1 and 2, swap tests were taken in a hospital kitchen to show the amount of infected areas. These results were also picked up from pre-processing zones for food, storage area and cooking area.

Biofilm is the form of $99 \%$ of bacteria in the kitchen. Biofilm formation makes the bacteria to be able to live in either biotic or abiotic surfaces. Therefore, another study on bacteria infecting kitchen surfaces is done as well [9]. Table 1 shows the total colony forming unit count on a cafeteria kitchen. It can be seen that the bacteria count is quite alarming even in dishwashers, sink, countertop areas, food waste container and pots. These are some areas that show that even bacteria would live in cleaning environment and cooking pots which would promote cross contamination. This also shows that the existing steps of cleaning could not disinfect microorganisms efficiently, and potential biofilm formation is not effectively prevented as well [9].

Table 1. Total colony forming unit (CFU) count on a cafeteria kitchen [9]

\begin{tabular}{|c|c|c|c|}
\hline $\begin{array}{l}\text { Surface } \\
\text { No. }\end{array}$ & Surface Area & $\begin{array}{l}\text { Total Aerobic } \\
\text { Count } \\
(\log \\
\left.\text { CFU } / 100 \mathrm{~cm}^{2}\right)\end{array}$ & Bacteria \\
\hline 1 & Cold Room & 5.90 & $\begin{array}{l}\text { Brachybacterium, Brevundimonas, } \\
\text { Kocuria, Pantoea, Paracoccus, } \\
\text { Roseomonas, Sphingobacterium }\end{array}$ \\
\hline 2 & $\begin{array}{l}\text { Pretreatment } \\
\text { Countertops }\end{array}$ & 3.83 & $\begin{array}{l}\text { Bacilus, Curtobacterium, Gordonia, } \\
\text { Kocuria, Pantoea, Pseudomonas, } \\
\text { Sphingomonas, Staphylococcus }\end{array}$ \\
\hline 3 & Sink & 4.14 & Bacillus, Enterobacter, Raoultella \\
\hline 4 & Faucet in the sink & 5.35 & $\begin{array}{l}\text { Bacillus, Enhydrobacter, Escherichia, } \\
\text { Kocuria }\end{array}$ \\
\hline 5 & $\begin{array}{l}\text { Roasting/frying } \\
\text { countertop }\end{array}$ & 3.63 & Bacillus, Kocuria, Lysinibacillus \\
\hline 6 & Spice rack & 4.84 & Bacillus, Microbacterium, Pantoea \\
\hline 7 & Soup pot & 3.59 & Acinetobacter, Bacillus \\
\hline 8 & Frying pot & 2.16 & Bacillus \\
\hline 9 & $\begin{array}{l}\text { Countertop for } \\
\text { completed menu }\end{array}$ & 3.16 & $\begin{array}{l}\text { Acidovorax, Acinetobacter, Bacillus, } \\
\text { Chryseobacterium, Deinococcus, } \\
\text { Enterobacter, Sphingomonas }\end{array}$ \\
\hline 10 & Rice cooker & 2.73 & $\begin{array}{l}\text { Acinetobacter, } \\
\text { Chryseobacterium, } \\
\text { Sphingomonas }\end{array}$ \\
\hline
\end{tabular}




\begin{tabular}{|c|c|c|c|}
\hline 11 & $\begin{array}{l}\text { Food } \\
\text { container }\end{array}$ & 3.21 & Bacillus, Staphylococcus \\
\hline 12 & Dishwasher & 2.53 & Bacillus \\
\hline 13 & $\begin{array}{ll}\text { Sink } & \text { for } \\
\text { dishwashing } & \end{array}$ & 2.86 & Bacillus \\
\hline 14 & $\begin{array}{l}\text { Stainless steel } \\
\text { trays }\end{array}$ & 1.60 & Bacillus \\
\hline 15 & $\begin{array}{l}\text { Plastic } \quad \text { wicker } \\
\text { tray }\end{array}$ & 4.07 & $\begin{array}{lr}\text { Acinetobacter, } & \text { Chryseobacterium, } \\
\text { Dermacoccus, } & \text { Exiguobacterium, } \\
\text { Kocuria, Pantoea } & \end{array}$ \\
\hline 16 & Iron roasting pan & 2.00 & Acinetobacter, Kocuria \\
\hline 17 & Knives & 2.00 & Acinetobacter, Bacillus \\
\hline 18 & $\begin{array}{l}\text { Cutting board } \\
\text { (Completed } \\
\text { Menu) }\end{array}$ & 2.45 & $\begin{array}{ll}\text { Arthrobacter, } & \text { Bacillus, } \\
\text { Curtobacterium, } & \text { Kocuria, } \\
\text { Microbacterium, Staphylococcus }\end{array}$ \\
\hline 19 & $\begin{array}{l}\text { Cutting board } \\
\text { (vegetables) }\end{array}$ & 2.97 & $\begin{array}{l}\text { Acinetobacter, } \\
\text { Enterobacter, Kocuria, Leclercia, } \\
\text { Methylobacterium, Roseomonas }\end{array}$ \\
\hline 20 & Gloves & 3.97 & Acinetobacter, Bacillus, Kocuria \\
\hline 21 & Apron & 6.85 & $\begin{array}{l}\text { Bacillus, Kocura, Pseudoxanthomonas, } \\
\text { Rhizobium }\end{array}$ \\
\hline 22 & Fan & 4.15 & Bacillus \\
\hline 23 & Floor & 4.65 & $\begin{array}{l}\text { Achromobacter, Aeromonas, Bacillus, } \\
\text { Cellulosimicrobium, } \\
\text { Chryseobacterium, Cloacibacterium, } \\
\text { Diaphorobacter, } \\
\text { Pseudomonas }\end{array}$ \\
\hline
\end{tabular}

Hence, in order to prevent cross contamination that will lead to foodborne diseases, studies have been done to optimize the cleaning processes in the kitchen and also trying out with different disinfectants and cleaning agents. Sterilizing of kitchen surfaces using a variety of disinfectants is one of the ways to minimize microorganisms living on surfaces and also preventing cross contamination. In this case, Taylor's Hospitality and Culinary Arts School (TCHT) is used as the model of research to find out how chemical and disinfectant washing can help in the cleaning of kitchen utensils. A table (Table 2) shows the volume of water and detergent needed to clean 6 kitchen utensils and 2 kitchen stoves.

Table 2. Volume of water used to clean 6 kitchen utensils and 2 kitchen stoves

\begin{tabular}{|l|l|l|}
\hline Items washed & $\begin{array}{l}\text { Amount of dishwashing } \\
\text { liquid used, ml }\end{array}$ & $\begin{array}{l}\text { Amount of water used for } \\
\text { cleaning, L }\end{array}$ \\
\hline 6 Kitchen utensils & 30 & 143.7 \\
\hline 2 Kitchen stoves & 15 & $5.9 \mathrm{~L}$ \\
\hline
\end{tabular}

TCHT has been searching for a way to reduce the cost of cleaning and also reducing the steps to do the cleaning so that cleaning of the kitchen would be faster and requires less man power. There are a few ways to optimize the current cleaning method to achieve TCHT's objective: 
1. In order to reduce chemical usage, TCHT has the possibility to use higher concentration of dishwashing liquid so that less chemical will be used to dilute in water but producing the same effect. However, more concentrated dishwashing liquid will also be higher cost.

2. In order to achieve less man power, the steps of cleaning have to be reduced. An alternative which can bypass the use of degreasing and too much scrubbing can reduce man power. In this case, the alternative way has to be good in sterilizing, degreasing and cleaning off dirt in one shot. Hence, reducing cleaning steps.

Cleaning using ozone technology is one way that can reduce the use of chemicals as ozone is well known to be a good disinfectant because of its highly reactive properties[10, 11]. Ozone is also proven by many ozone technology companies to be a good degreaser. Hence, ozone is widely used in the western part of the world in industry cleaning, sterilizing and degreasing. However, ozone is not as well known in this tropical region as in the western world. Ozone technology is not unknown in kitchen area as ozone is also used in cleaning vegetables and fruits before cooking. One of the examples is in the cleaning of spinach [12].

Hence, this research is to introduce the usage of ozone technology in order to enhance and improve the ways to clean the kitchen utensils which takes up most of the cleaning time in Taylor's Hospitality and Culinary Arts School. The objective is to customize and develop designs to bring out effective applications of ozone technology in cleaning kitchen utensils. Furthermore, the research is carried out also to prove that the usage of ozone technology reduces the usage of chemicals, man powers and time consumption in cleaning process.

\section{Methodology}

This research is done by cleaning stainless steel kitchen utensils in Taylor's Hospitality and Culinary Arts (TCHT). The research done on different methods is shown in Table 3.

Table 3. Methods of testing

\begin{tabular}{|l|l|}
\hline With Nozzle & Without Nozzle \\
\hline Without ozone & Without ozone \\
\hline With ozone & With ozone \\
\hline
\end{tabular}

\subsection{Calculation of water and chemical usage in cleaning process}

A water flow meter shown in Fig. 1 is attached to the outlet of the water pipe where water flows out for kitchen utensil washing. This is to measure the amount of water used during the whole cleaning process. The amount of water used is compared between the cleaning with and without ozone, and with and without nozzles. The volume of water was controlled during the research, not letting it to overrun before and after washing. The water was only let run when needed. 


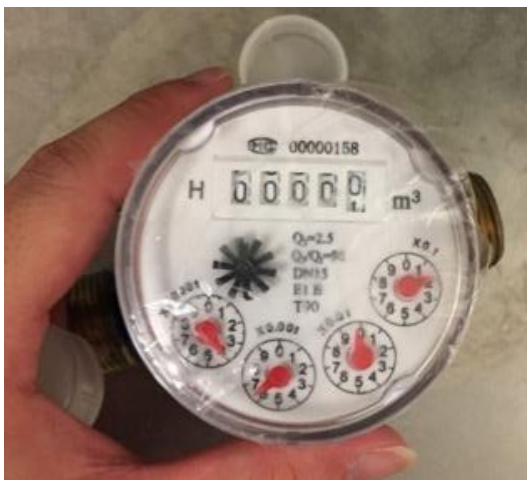

Fig. 1. Water flow meter with readings in $\mathrm{m}^{3}$

A $10 \mathrm{ml}$ syringe shown in Fig. 2 is used to measure the volume of dishwashing liquid used to clean the kitchen utensils. The dishwashing liquid is already diluted with the ratio of $1 \mathrm{~L}$ of detergent to $20 \mathrm{~L}$ of water. It is tested with the same methods as in Table 2. The detergent is added on by an increment of $1 \mathrm{ml}$ onto the dishwashing sponge until the worker feels that it is sufficient to clean the pot. This is done to ease the calculation for the efficiency of ozone water cleaning vs non-ozone water cleaning.

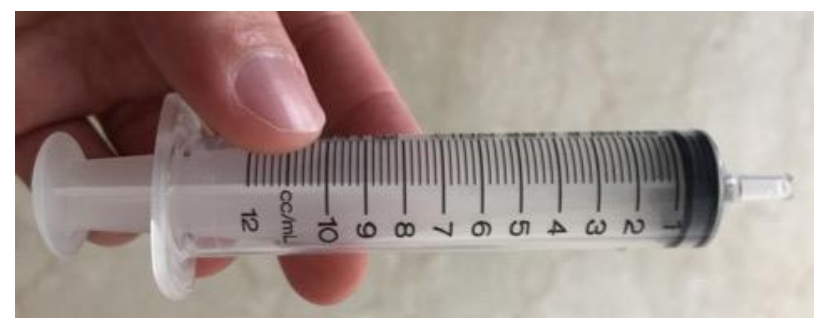

Fig. 2. $10 \mathrm{ml}$ syringe for dishwashing liquid measurement

\subsection{Customization of ozone machine}

The ozone machine in Fig. 3 is provided by Medklinn International Sdn Bhd. The ozone capacity used was $500 \mathrm{mg} / \mathrm{hr}$. Ozone is also produced with the presence of oxygen as stated in the literature review. In this case, a consistent provided of oxygen is needed so that the ozone produced will be consistent as well. Therefore, an oxygen concentrator is used to provide the consistent amount of oxygen. A 1 LPM oxygen concentrator is used for this research. A venturi shown in Fig. 4 is used for suction of ozone gas to be diluted in water is MK584 (3/4 inch inlet and outlet size). This will result in a 1.8 particles per million (PPM) (without nozzle) and 1.25 PPM (with nozzle) concentration of ozone. 


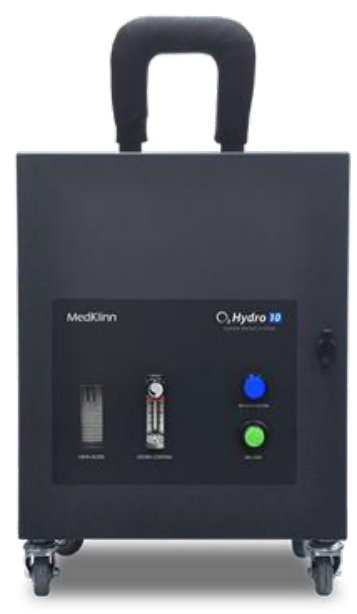

Fig. 3. Ozone Machine

Inlet (higher pressure)

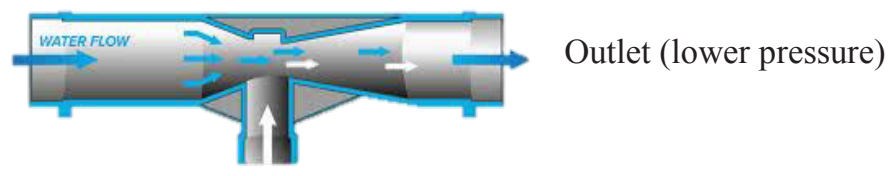

Suction of gas or liquid

Fig. 4. MK584 Venturi [13]

\subsection{Nozzle profile}

A nozzle is used to have a higher water impact in the cleaning process to remove oil and stubborn dirt on the kitchen utensils. The nozzle design has 16 linear $1.50 \mathrm{~mm}$ diameter circular holes with a $3 \mathrm{~mm}$ linear distance between each hole. Fig. 5 shows the design of the nozzle used to clean the kitchen utensils. The design has the same number of holes compared to the nozzle used in the traditional way of cleaning in Taylors School of Hospitality and Culinary Arts (TCHT). However, the nozzle profile in TCHT is a shower pattern nozzle. A shower pattern nozzle shows a lower impact force compared to the one in linear. This is because most of the water flow is not blocked at the outlet, hence there is lesser force that pushes the water out of the orifices. However, in linear, the water is constrained to exit only at the middle of the outlet. Hence, pressure accumulates in the nozzle and more force is present to push the water out of the orifices. 

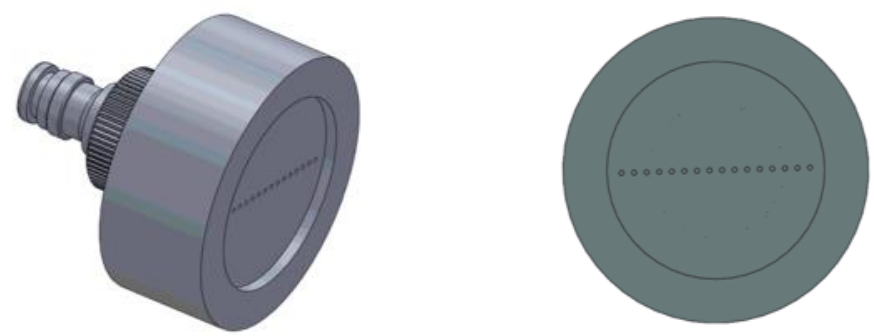

Fig. 5. Linear Circular Pattern Nozzle

ANSYS Fluent CFD is running on the nozzle profile to identify the velocity profile and also the pressure at the outlet. A multi-zone, mapped mesh type hexa/prism and free mesh type of tetra/pyramid meshing is done [Fig. 6]. Multi-zone, hex dominant is done because the outlets of the nozzles are having circular patterns and multi-zone work best for these conditions. It has a total of 108202 numbers of elements, average skewness 0.36274 and an average orthogonal quality of 0.79 .

For the boundary conditions, Reynold's number is calculated for the flow to see whether the flow is a laminar or turbulent flow across the nozzle. The equation for Reynold's number is as follow:

$$
\text { Reynold's number }=\frac{\rho v D}{\mu}(\text { Eq. 1) }
$$

Where,

$\rho$ : Density of water

$v$ : Velocity of water

$\mu$ : Viscocity of water at $28^{\circ} \mathrm{C}$

According to [14], viscosity and the density of water at $28^{\circ} \mathrm{C}$ is $0.8324 \mathrm{mPa}$.s and 0.9962 $\mathrm{g} / \mathrm{cm}^{3}$ respectively.

$$
\text { Reynold's number }=\frac{996.2 \frac{\mathrm{kg}}{\mathrm{m}^{\mathrm{g}}} \times 3 \frac{\mathrm{m}}{\mathrm{g}} \times 0.0092 \mathrm{~m}}{0.8324 \times 0.001 \frac{\mathrm{kg}}{\mathrm{ms}}}=33,031.14
$$

The flow is turbulent, Realizable k- $\varepsilon$ is used as the viscous modelling during all the CFD analysis. The boundary conditions are set to $3 \mathrm{~m} / \mathrm{s}$ inlet velocity with. This is due to the volumetric flow rate of 12 LPM measured from the pipes of the kitchen in Taylor's School of Hospitality and Culinary Arts. 


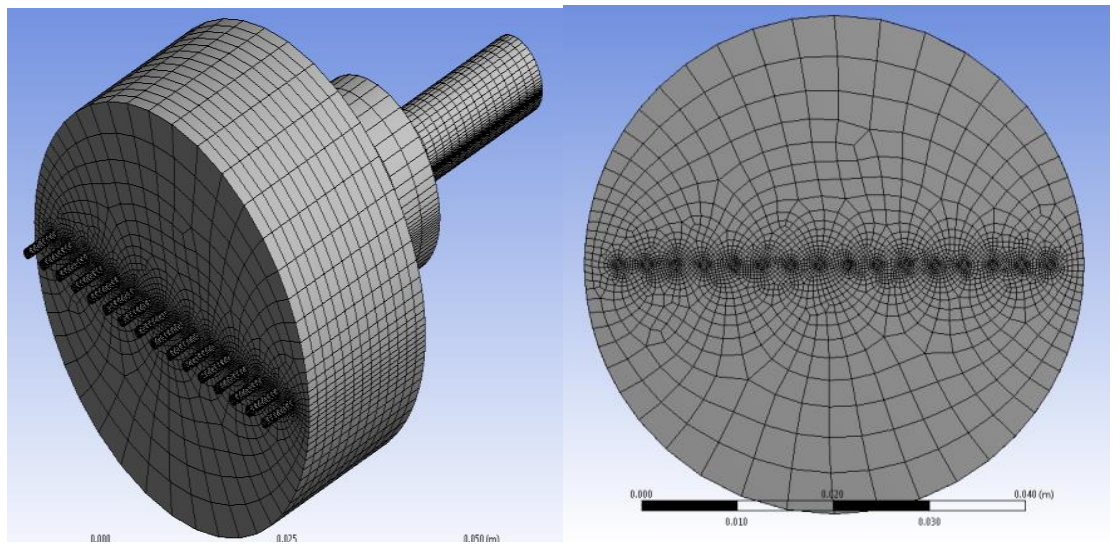

Fig. 6. Multi-zone mesh type

\subsection{Cleanliness of kitchen utensil}

3M Clean Trace shown in Fig. 7 is used as the equipment to test on the cleanliness of the kitchen utensil. Swabs are taken before and after cleaning of the kitchen utensil using the traditional way (without ozone water) and with ozone water. A cotton bud like stick shown in Fig. 7 are used to swab on the surface $(10 \mathrm{~cm} \times 10 \mathrm{~cm})$ of the kitchen pot before cleaning, and done it again after cleaning. Same applies to with and without nozzle. The measurement is taken as Relative Light Units (RLU). RLU is the measurement of adenosine triphosphate (ATP) present on the kitchen utensil. The higher the RLU, the dirtier the kitchen utensil is. In normal practice, RLU higher than 11 is a caution and higher than 30 is a fail. Hence, RLU lower than 10 is in the safe region [15].
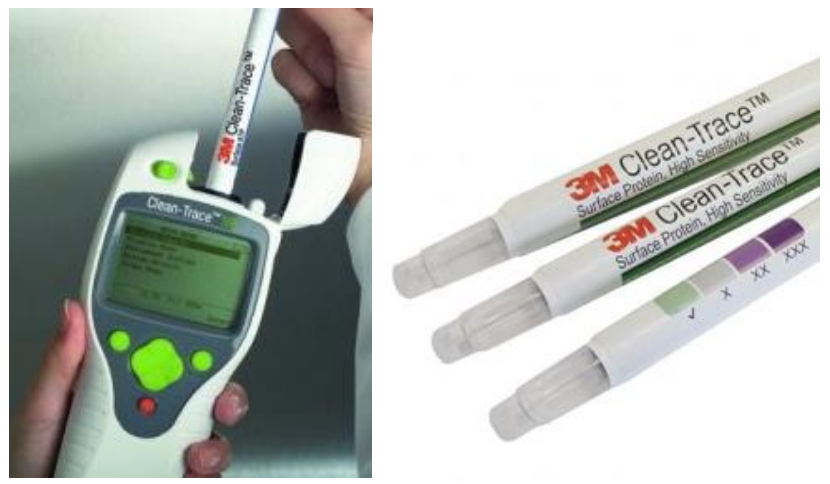

Fig. 7. 3M Clean Trace swab sticks

Kitchen towel and an oil control blotting paper are used to have a qualitative result on the dirt and oil left on the kitchen utensil after cleaning. Results are shown in the next section of discussion. 


\section{Results and discussion}

\subsection{Washing of stainless steel pot}

Table 4 and 5 show the amount of water and detergent is used for the different methods of washing (as discussed in Table 2). The tables also show the cleanliness (RLU) of the pots before and after washing. Comparing the results with the background reading in Table 2, averagely one utensil needed $23.95 \mathrm{~L}$ of water to clean. However, during the research, the volume of water was controlled well hence, there is a big reduction in the volume of water.

Table 4. Cleaning of a stainless steel kitchen pot without nozzle

\begin{tabular}{|c|c|c|}
\hline Variables & Traditional way & Ozone water \\
\hline Volume of water, L & 10.4 & 11.1 \\
\hline $\begin{array}{l}\text { Volume of detergent, } \\
\mathrm{ml}\end{array}$ & 4 & 6 \\
\hline Ozone level, PPM & - & 1.8 \\
\hline \multicolumn{3}{|l|}{ Pot before washing } \\
\hline $\begin{array}{l}\text { Cleanliness before } \\
\text { washing, RLU }\end{array}$ & 674 & 312 \\
\hline \multicolumn{3}{|l|}{ Pot after washing } \\
\hline \multicolumn{3}{|l|}{$\begin{array}{l}\text { Oil and dirt detection } \\
\text { after washing }\end{array}$} \\
\hline $\begin{array}{l}\text { Cleanliness after } \\
\text { washing, RLU } \\
\text { (TOTAL } \\
\text { REDUCTION OF } \\
\text { RLU) }\end{array}$ & $226(448)$ & $103(209)$ \\
\hline Temperature of water & $29.6^{\circ} \mathrm{C}$ & $29.1^{\circ} \mathrm{C}$ \\
\hline
\end{tabular}


Table 5. Cleaning of a stainless steel kitchen pot with nozzle

\begin{tabular}{|c|c|c|}
\hline Variables & Traditional way & Ozone water \\
\hline $\begin{array}{l}\text { Volume of } \\
\text { water, L }\end{array}$ & 8 & 8 \\
\hline $\begin{array}{l}\text { Volume of } \\
\text { detergent, ml }\end{array}$ & 5 & 5 \\
\hline $\begin{array}{l}\text { Ozone level, } \\
\text { PPM }\end{array}$ & - & $1.25 \mathrm{ppm}$ \\
\hline $\begin{array}{l}\text { Pot before } \\
\text { washing }\end{array}$ & & \\
\hline $\begin{array}{l}\text { Cleanliness } \\
\text { before washing, } \\
\text { RLU }\end{array}$ & 1106 & 679 \\
\hline \multicolumn{3}{|l|}{ Pot after washing } \\
\hline $\begin{array}{l}\text { Oil and dirt } \\
\text { detection after } \\
\text { washing }\end{array}$ & & \\
\hline $\begin{array}{l}\text { Cleanliness after } \\
\text { washing, RLU } \\
\text { (TOTAL } \\
\text { REDUCTION } \\
\text { OF RLU) }\end{array}$ & $156(950)$ & $6(673)$ \\
\hline $\begin{array}{l}\text { Temperature of } \\
\text { water }\end{array}$ & $29.5^{\circ} \mathrm{C}$ & $29.1^{\circ} \mathrm{C}$ \\
\hline
\end{tabular}


From Table 4, the RLU reduction for traditional way of cleaning (using just detergent and normal $29.6^{\circ} \mathrm{C}$ of water) is $66.47 \%$ while for ozone water is $67 \%$. Traditional way uses $700 \mathrm{ml}$ of water and $2 \mathrm{ml}$ of detergent lesser compared to ozone water to achieve the RLU. The difference in water volume and detergent, and also the RLU reduction are not significant in this experiment. Table 5 shows a significant difference in RLU reduction comparing the two methods of cleaning with the same amount of water and detergent used. There was a $85.9 \%$ reduction using the traditional way with nozzle and a $99.12 \%$ RLU reduction using ozone with nozzle. This has significantly shown that with the use of nozzle in the cleaning process, it increases the RLU reduction by about $20 \% \sim 30 \%$ compared to without the nozzle. Ozone water with the use of nozzle also shown the cleaning process to be very efficient.

The readings are as such because it is due to the properties of nozzle. Although with nozzle, the PPM level is lower than the one without nozzle, however nozzle plays a part in cleaning and also sterilizing. Ozone needs exposure time to the surface in order to kill bacteria, hence when ozone without nozzle is applied, the reduction rate is slower. When nozzle is applied in this case, the nozzle will give impact force to the utensil surface and clearing most of the dirt and bacteria, adding on with ozone, the sterilizing effect is much higher compared to without the nozzle.

So, comparing with nozzle with ozone and without ozone, although both shows more than $80 \%$ of RLU reduction, the one without ozone has always show RLU more than 10 which is unsafe to use according to [41]. When comparing without nozzle with ozone and without ozone, both have also failed to the requirement stated in [41]. Hence, ozone and nozzle is the best combination as the RLU reduction for all the cases has shown RLU less than 10, which is safe for consumers. This has proven that even though chemicals are used to wash utensils, it might not be safe for consumption purposes. Ozone has proven to be a strong disinfectant and the utensils that are cleansed by ozone will be definitely safe to use.

\subsection{Nozzle and ozone suction in water}

The inlet velocity is at $3 \mathrm{~m} / \mathrm{s}$ and the outlet velocity as the result of the nozzle design is at about $12-14 \mathrm{~m} / \mathrm{s}$. Fig. 9 shows the velocity path lines of the flow of water through the nozzle. It can also be seen that there is back flow occurring as it hits the head of the nozzle. The backflow also causes the high pressure of $1 \times 10^{5} \mathrm{~Pa}$ to be accumulated in the nozzle itself as shown in Fig. 10. As the pressure accumulates in the nozzle, the velocity decreases, the air pressure in the venturi will find it difficult to push the ozone gas to dilute in the water through the venturi. This causes the decrease in ozone suction in the venturi which was from 1.8 PPM to 1.25 PPM (from Table 4 and 5). 


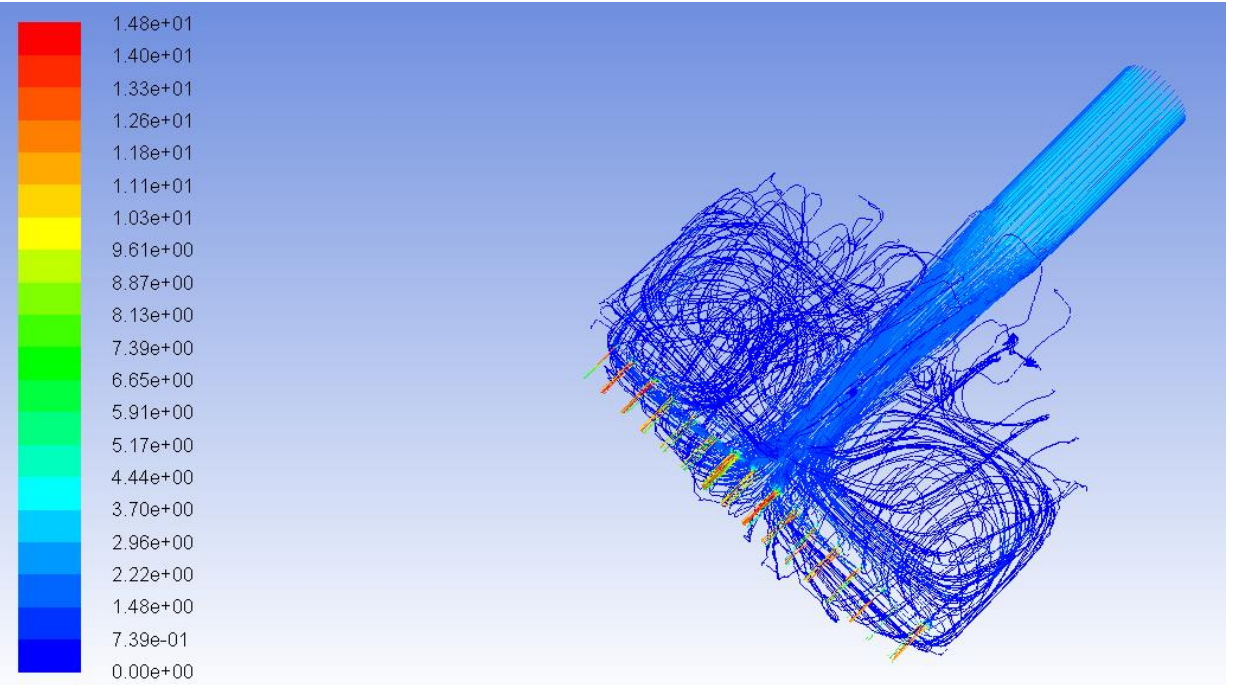

Fig. 9. Velocity path lines

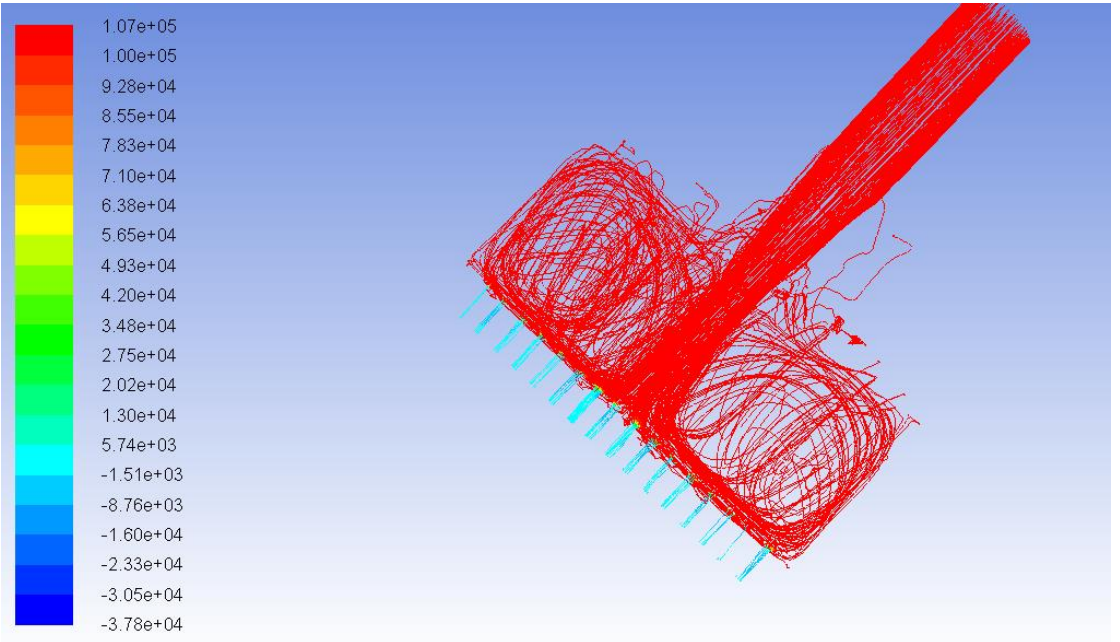

Fig. 10. Pressure path lines

According to [16], the impact force is based on the angle of water distribution from the nozzle. The bigger the angle of water distribution, the lower the impact force. This is because of the kinetic energy losses when it is needed to distribute the water at the big angles. Since the impact force equation is given by,

$$
F s=\frac{1}{2} m v^{2}(\text { Eq. 2) }
$$

where the velocity at the outlet will play a part in determining the impact force. When the velocity is higher at the outlet, the impact force will be higher.

The design of the conventional nozzle is based on the nozzle used in TCHT kitchen shown in Appendix 3 and 4. According to literature review [16, 17], a nozzle that produces solid stream has the highest impact force compared to water distributed at an angle. Single hole will give a solid stream flow. However, a solid stream will also lose momentum quicker compared to others, even though all nozzles will lose momentum after the water exits from the orifice [17]. Hence, the distance of nozzle to the surface intended to be washed have to 
be nearer so that the water can hit the surface with minimal losses of momentum. A single hole is also not very user friendly to wash kitchen utensil as the focus area is small and usually a kitchen utensil is at sizes of $10 \mathrm{~cm}-20 \mathrm{~cm}$. So in order to optimize the washing, a linear pattern is done with $3 \mathrm{~mm}$ apart so that the water streams could wash the kitchen utensil at a bigger surface area. It can mimic a fan pattern nozzle but having solid streams as well to increase impact force.

\section{Conclusion}

In conclusion, the usage of ozone water in cleaning kitchen utensils has shown significant difference compared to using the traditional way of cleaning with the aid of a nozzle. The nozzle prototype has given the cleaning process a huge boost with a big increment of RLU reduction. The kitchen utensil is tested to be $99 \%$ clean after using ozone with the same amount of water and dishwashing liquid as to the traditional way of cleaning. The controlled research has definitely reduced the volume of water used and proven to be much more efficient in cleaning. In terms of manpower, there is no reduction because the time of cleaning is almost the same. The nozzle could help to ease the cleaning of stubborn dirt however, the time of cleaning is almost the same with and without nozzle. Ozone level in the water is also based on the pressure of water, as the backpressure is high, the ozone level dissolved in the water is lesser.

\section{Acknowledgement}

Throughout this research, I would like to acknowledge a few people that have guided me. Firstly, I would like to thank Medklinn International Sdn Bhd, for providing me the equipment to carry out the experiments. My extended acknowledgement to my industrial supervisor Mr. Lim Boon Han and Mr. Daniel Lu for giving me his advice based on his knowledge and experience in the ozone industry. I would also like to thank Taylor's School of Hospitality and Culinary Arts for the opportunity to allow me to carry out my research in the kitchen, alongside the supervision of Mr. Hisammudin and Mr. Kumar, the people in charge of the kitchen.

\section{References}

[1] J. S. Hargreaves and B. Cantab, "Laboratory Evaluation of the 3-Bowl System Used for Washing-Up Eating Utensils in the Field," Wilderness Environ. Med., vol. 17, no. 2, pp. 94-102, 2006.

[2] F. Chaib and Olivia Lawe-Davies, "WHO's first ever global estimates of foodborne diseases find children under 5 account for almost one third of deaths," 2017. [Online]. Available: $\quad$ http://www.who.int/mediacentre/news/releases/2015/foodborne-diseaseestimates/en/. [Accessed: 17-Jun-2017]. 
[3] K. Mattick et al., "The survival of foodborne pathogens during domestic washing-up and subsequent transfer onto washing-up sponges, kitchen surfaces and food," vol. 85, pp. 213-226, 2003.

[4] H. Protection, A. Communicable, D. Surveillance, H. Protection, A. Specialist, and R. M. Division, "Foodborne general outbreaks of Salmonella Enteritidis phage type 4 infection, England and Wales , 1992 - 2002 : where are the risks ?," pp. 795-801, 2005.

[5] A. Valero, J. Carlos, G. Fongaro, M. Hern, and D. Rodríguez-1, "De fi nition of sampling procedures for collective-eating establishments based on the distribution of environmental microbiological contamination on food handlers, utensils and surfaces," vol. 77, no. 852, pp. 8-16, 2017.

[6] H. Sciences and Y. Sakyo-ku, "A study on Campylobacter jejuni cross-contamination during chilled broiler preparation," vol. 115, pp. 107-115, 2010.

[7] G. Stellato, A. La Storia, T. Cirillo, and D. Ercolini, "International Journal of Food Microbiology Bacterial biogeographical patterns in a cooking center for hospital foodservice," Int. J. Food Microbiol., vol. 193, pp. 99-108, 2015.

[8] F. Timothy, "Risk of Giardiasis from Consumption of Wilderness Water in North America : A Systematic Review of Epidemiologic Data,” pp. 100-103.

[9] E. Seob, J. Eun, J. Kim, and O. Kyung, "LWT - Food Science and Technology Isolation of indigenous bacteria from a cafeteria kitchen and their bio fi $1 \mathrm{~m}$ formation and disinfectant susceptibility," LWT - Food Sci. Technol., vol. 77, pp. 376-382, 2017.

[10] G. H. R. Silva, L. A. Daniel, H. Bruning, and W. H. Rulkens, "Bioresource Technology Anaerobic effluent disinfection using ozone: Byproducts formation," Bioresour. Technol., vol. 101, no. 18, pp. 6981-6986, 2010.

[11] S. Tripathi, V. Pathak, D. M. Tripathi, and B. D. Tripathi, "Bioresource Technology Application of ozone based treatments of secondary effluents," Bioresour. Technol., vol. 102, no. 3, pp. 2481-2486, 2011.

[12] M. V Shynkaryk, T. I. Pyatkovskyy, A. E. Yousef, and S. K. Sastry, "Gaseous ozone treatment of baby spinach within the existing production chain for inactivation of Escherichia coli O157 : H7," J. Food Eng., vol. 191, pp. 10-18, 2016.

[13] "Venturi Fertilizer Applications - Wassertec. Cape Town", Wassertec.co.za, 2017. [Online]. Available: https://www.wassertec.co.za/venturi-fertilizer-applications/. [Accessed: 17- Jun- 2017].

[14] "Water - viscosity table and viscosity chart", Viscopedia.com, 2017. [Online]. Available: http://www.viscopedia.com/viscosity-tables/substances/water/. [Accessed: 17Nov- 2017]. 
[15] "Food \& Beverage - Hygiena Monitoring Systems - Setting ATP Limits - RLU Limits | Food and Beverage Products | Hygiena | Hygiena - Rapid Solutions for Hygiene Monitoring", Hygiena.com, 2017. [Online]. Available: https://www.hygiena.com/rlulimitsfood.html. [Accessed: 26- Oct- 2017].

[16] "Cleaning", Spray-nozzle.co.uk, 2017. [Online]. Available: http://www.spraynozzle.co.uk/spray-nozzles-by-industry/food-processing-new/cleaning. [Accessed: 20Nov- 2017].

[17] "Solid Stream Nozzles for cleaning applications", Spray-nozzle.co.uk, 2017. [Online]. Available: http://www.spray-nozzle.co.uk/resourcelinks/applications/cleaning/solid-stream-nozzles. [Accessed: 17- Nov- 2017]. 


\section{APPENDIX}

\begin{tabular}{|c|c|c|c|c|c|c|c|c|c|c|c|c|c|c|}
\hline \multicolumn{2}{|l|}{ Taxon } & \multirow{2}{*}{$\begin{array}{l}\text { S_BlastChiller_Wall } \\
0.003\end{array}$} & \multirow{2}{*}{ S_ColdStorage_Shelf } & \multirow{2}{*}{$\begin{array}{l}\text { S_ColdStorage_Wall } \\
0.001\end{array}$} & \multirow{2}{*}{$\begin{array}{l}\text { K.Balance } \\
0.004\end{array}$} & \multirow{2}{*}{$\begin{array}{l}\text { K_Sink } \\
0.009\end{array}$} & \multirow{2}{*}{$\begin{array}{l}\text { K.Workbench } \\
0.001\end{array}$} & \multirow{3}{*}{$\begin{array}{l}\text { PPF_Sink } \\
0.000 \\
0.001\end{array}$} & \multicolumn{2}{|c|}{ PPF_Workbench } & \multirow{2}{*}{$\begin{array}{l}\text { PPR_Cutter } \\
0.001\end{array}$} & \multirow{2}{*}{$\begin{array}{l}\text { PPR_Sink } \\
0.017\end{array}$} & PPR_Workbench & PPV_CuttingBoard \\
\hline \multirow{2}{*}{\multicolumn{2}{|c|}{$\begin{array}{l}\text { Acinetobacter } \\
\text { Acinetobacter johnsonii }\end{array}$}} & & & & & & & & 0.012 & & & & 0.001 & 0.000 \\
\hline & & 0.004 & 0.071 & 0.007 & 0.005 & 0.096 & 0.001 & & 0.009 & & 0.001 & 0.079 & 0.001 & 0.000 \\
\hline \multirow{2}{*}{\multicolumn{2}{|c|}{$\begin{array}{l}\text { Alicyclobacillus } \\
\text { Coulobacter }\end{array}$}} & 0.266 & 0.029 & 0.127 & 0.000 & 0.020 & 0.041 & 0.030 & 0.107 & & 0.000 & 0.021 & 0.049 & 0.001 \\
\hline \multirow{2}{*}{\multicolumn{2}{|c|}{ Chryseobacterium }} & 0.001 & 0.002 & 0.001 & 0.000 & 0.001 & 0.000 & 0.002 & 0.008 & & 0.000 & 0.001 & 0.000 & 0.046 \\
\hline & & 0.000 & 0.002 & 0.000 & 0.001 & 0.030 & 0.000 & 0.000 & 0.010 & & 0.000 & 0.014 & 0.000 & 0.003 \\
\hline Corynebacteriut & & 0.003 & 0.001 & 0.007 & 0.000 & 0.009 & 0.000 & 0.002 & 0.000 & & 0.000 & 0.002 & 0.000 & 0.001 \\
\hline Enterococcus lac & & 0.000 & 0.006 & 0.002 & 0.001 & 0.017 & 0.000 & 0.000 & 0.000 & & 0.022 & 0.040 & 0.000 & 0.000 \\
\hline & & 0.011 & 0.058 & 0.042 & 0.000 & 0.024 & 0.001 & 0.116 & 0.040 & & 0.000 & 0.070 & & \\
\hline Kocuria marina & & 0.000 & 0.002 & 0.000 & 0.000 & 0.000 & 0.000 & 0.002 & 0.002 & & 0.000 & 0.001 & 0.002 & 0.000 \\
\hline Kocuria palustri & & 0.006 & 0.010 & 0.006 & 0.000 & 0.012 & 0.000 & 0.006 & 0.000 & & 0.000 & 0.028 & 0.002 & 0.000 \\
\hline Lactobacillus & & 0.004 & 0.000 & 0.007 & 0.000 & 0.002 & 0.001 & 0.015 & 0.004 & & 0.000 & 0.001 & 0.000 & 0.000 \\
\hline Massilia timona & & 0.004 & 0.003 & 0.001 & 0.000 & 0.007 & 0.000 & 0.100 & 0.004 & & 0.000 & 0.000 & 0.000 & 0.091 \\
\hline Moraxellaceae & & 0.000 & 0.002 & 0.000 & 0.000 & 0.005 & 0.000 & 0.006 & 0.003 & & 0.000 & 0.002 & 0.000 & 0.000 \\
\hline Paracoccus & & 0.017 & 0.007 & 0.009 & 0.000 & 0.018 & 0.000 & 0.084 & 0.004 & & 0.003 & 0.003 & 0.001 & 0.104 \\
\hline Propionibacteri & & 0.025 & 0.004 & 0.009 & 0.000 & 0.001 & 0.006 & 0.004 & 0.015 & & 0.000 & 0.001 & 0.002 & 0.000 \\
\hline Pseudomonas & & 0.028 & 0.024 & 0.011 & 0.241 & 0.258 & 0.273 & 0.001 & 0.002 & & 0.426 & 0.010 & 0.603 & 0.001 \\
\hline Psychrobacter & & 0.110 & 0.190 & 0.005 & 0.316 & 0.023 & 0.236 & 0.093 & 0.001 & & 0.110 & 0.192 & 0.000 & 0.000 \\
\hline Ralstonia & & 0.005 & 0.000 & 0.006 & 0.000 & 0.001 & 0.004 & 0.003 & 0.007 & & 0.001 & 0.001 & 0.001 & 0.000 \\
\hline Serratia & & 0.007 & 0.000 & 0.019 & 0.000 & 0.001 & 0.002 & 0.002 & 0.004 & & 0.000 & 0.003 & 0.001 & 0.000 \\
\hline Sphingomonas & & 0.006 & 0.001 & 0.006 & 0.000 & 0.002 & 0.000 & 0.015 & 0.000 & & 0.000 & 0.001 & 0.001 & 0.057 \\
\hline Staphylococcus & & 0.005 & 0.008 & 0.003 & 0.000 & 0.007 & 0.002 & 0.002 & 0.000 & & 0.000 & 0.004 & 0.000 & 0.000 \\
\hline Streptococcus & & 0.002 & 0.003 & 0.012 & 0.000 & 0.002 & 0.001 & 0.004 & 0.013 & & 0.000 & 0.002 & 0.000 & 0.000 \\
\hline Streptococcus se & guinis & 0.051 & 0.018 & 0.140 & 0.000 & 0.030 & 0.011 & 0.018 & 0.035 & & 0.006 & 0.070 & 0.007 & 0.001 \\
\hline Streptococcus th & mophilus & 0.005 & 0.002 & 0.005 & 0.000 & 0.003 & 0.002 & 0.002 & 0.004 & & 0.001 & 0.004 & 0.000 & 0.000 \\
\hline other & & 0.018 & 0.047 & 0.022 & 0.011 & 0.023 & 0.016 & 0.023 & 0.046 & & 0.010 & 0.014 & 0.009 & 0.016 \\
\hline PPV_Grinder & PPV_Sink & PPV_Workbench & PPW_Sink & PPW_Workbench & T_Colander & $\mathrm{T}_{-} \mathrm{Cu}$ & uttingBoard & T_Knife & T_Pan & T_Steel[ & Dish & T_SteelPincers & T_Steelshovel & T_SteelTray \\
\hline 0.015 & 0.082 & 0.010 & 0.018 & 0.026 & 0.007 & 0.001 & & 0.000 & 0.001 & 0.000 & & 0.003 & 0.392 & 0.001 \\
\hline 0.001 & 0.031 & 0.033 & 0.033 & 0.100 & 0.793 & 0.000 & & 0.001 & 0.012 & 0.001 & & 0.004 & 0.004 & 0.003 \\
\hline 0.001 & 0.000 & 0.166 & 0.092 & 0.210 & 0.036 & 0.000 & & 0.005 & 0.313 & 0.002 & & 0.121 & 0.020 & 0.058 \\
\hline 0.001 & 0.022 & 0.002 & 0.005 & 0.006 & 0.000 & 0.000 & & 0.000 & 0.004 & 0.000 & & 0.001 & 0.001 & 0.003 \\
\hline 0.017 & 0.029 & 0.005 & 0.006 & 0.027 & 0.005 & 0.007 & & 0.000 & 0.000 & 0.002 & & 0.001 & 0.006 & 0.000 \\
\hline 0.009 & 0.000 & 0.002 & 0.010 & 0.002 & 0.001 & 0.003 & & 0.005 & 0.002 & 0.000 & & 0.001 & 0.001 & 0.003 \\
\hline 0.000 & 0.000 & 0.000 & 0.001 & 0.000 & 0.000 & 0.000 & & 0.002 & 0.001 & 0.000 & & 0.018 & 0.007 & 0.000 \\
\hline 0.076 & 0.000 & 0.008 & 0.086 & 0.049 & 0.000 & 0.015 & & 0.322 & 0.002 & 0.014 & & 0.010 & 0.001 & 0.002 \\
\hline 0.002 & 0.000 & 0.000 & 0.001 & 0.002 & 0.001 & 0.001 & & 0.005 & 0.000 & 0.000 & & 0.001 & 0.000 & 0.000 \\
\hline 0.198 & 0.000 & 0.001 & 0.022 & 0.005 & 0.000 & 0.000 & & 0.005 & 0.000 & 0.002 & & 0.001 & 0.000 & 0.001 \\
\hline 0.000 & 0.000 & 0.011 & 0.033 & 0.004 & 0.001 & 0.002 & & 0.001 & 0.023 & 0.000 & & 0.003 & 0.001 & 0.007 \\
\hline 0.049 & $\begin{array}{l}0.137 \\
0.007\end{array}$ & $\begin{array}{l}0.002 \\
0.002\end{array}$ & $\begin{array}{l}0.061 \\
0.043\end{array}$ & $\begin{array}{l}0.006 \\
0.017\end{array}$ & 0.001 & 0.000 & & 0.000 & 0.000 & 0.000 & & 0.001 & 0.001 & 0.000 \\
\hline $\begin{array}{l}0.001 \\
0.023\end{array}$ & $\begin{array}{l}0.002 \\
0.088\end{array}$ & 0.002 & $\begin{array}{l}0.043 \\
0.004\end{array}$ & $\begin{array}{l}0.017 \\
0.013\end{array}$ & $\begin{array}{l}0.001 \\
0.000\end{array}$ & 0.101 & & 0.024 & 0.000 & 0.000 & & 0.004 & 0.001 & 0.001 \\
\hline $\begin{array}{l}0.023 \\
0.010\end{array}$ & $\begin{array}{l}0.088 \\
0.000\end{array}$ & $\begin{array}{l}0.009 \\
0.034\end{array}$ & $\begin{array}{l}0.004 \\
0.004\end{array}$ & $\begin{array}{l}0.013 \\
0.008\end{array}$ & $\begin{array}{l}0.000 \\
0.0003\end{array}$ & 0.000 & & $\begin{array}{l}0.0000 \\
0.0000\end{array}$ & $\begin{array}{l}0.002 \\
0.016\end{array}$ & 0.079 & & $\begin{array}{l}0.001 \\
0.010\end{array}$ & $\begin{array}{l}0.012 \\
0.003\end{array}$ & $\begin{array}{l}0.002 \\
0.034\end{array}$ \\
\hline $\begin{array}{l}0.010 \\
0.001\end{array}$ & $\begin{array}{l}0.000 \\
0.040\end{array}$ & $\begin{array}{l}0.034 \\
0.038\end{array}$ & $\begin{array}{l}0.004 \\
0.007\end{array}$ & $\begin{array}{l}0.008 \\
0.007\end{array}$ & $\begin{array}{l}0.003 \\
0.019\end{array}$ & $\begin{array}{l}0.000 \\
0.092\end{array}$ & & $\begin{array}{l}0.000 \\
0.029\end{array}$ & $\begin{array}{l}0.016 \\
0.006\end{array}$ & $\begin{array}{l}0.000 \\
0.000\end{array}$ & & $\begin{array}{l}0.010 \\
0.003\end{array}$ & $\begin{array}{l}0.003 \\
0.004\end{array}$ & $\begin{array}{l}0.034 \\
0.002\end{array}$ \\
\hline 0.094 & $\begin{array}{l}0.040 \\
0.000\end{array}$ & 0.008 & 0.005 & 0.001 & 0.004 & 0.276 & & $\begin{array}{l}0.029 \\
0.035\end{array}$ & $\begin{array}{l}0.006 \\
0.000\end{array}$ & $\begin{array}{l}0.000 \\
0.001\end{array}$ & & $\begin{array}{l}0.003 \\
0.011\end{array}$ & $\begin{array}{l}0.004 \\
0.001\end{array}$ & $\begin{array}{l}0.002 \\
0.002\end{array}$ \\
\hline 0.000 & 0.000 & 0.008 & 0.001 & 0.009 & 0.000 & 0.000 & & 0.000 & 0.011 & 0.000 & & 0.007 & 0.001 & 0.032 \\
\hline 0.000 & 0.000 & 0.016 & 0.001 & 0.007 & 0.001 & 0.000 & & 0.000 & 0.043 & 0.000 & & 0.006 & 0.000 & 0.003 \\
\hline 0.000 & 0.026 & 0.003 & 0.007 & 0.005 & 0.001 & 0.000 & & 0.000 & 0.004 & 0.033 & & 0.000 & 0.001 & 0.001 \\
\hline 0.000 & 0.000 & 0.010 & 0.014 & 0.004 & 0.001 & 0.000 & & 0.000 & 0.004 & 0.000 & & 0.001 & 0.000 & 0.004 \\
\hline 0.000 & 0.000 & 0.015 & 0.005 & 0.003 & 0.002 & 0.000 & & 0.000 & 0.011 & 0.000 & & 0.028 & 0.002 & 0.032 \\
\hline 0.001 & 0.000 & 0.088 & 0.026 & 0.058 & 0.032 & 0.100 & & 0.017 & 0.267 & 0.001 & & 0.052 & 0.032 & 0.076 \\
\hline 0.000 & 0.000 & 0.008 & 0.003 & 0.005 & 0.001 & 0.003 & & 0.000 & 0.013 & 0.000 & & 0.007 & 0.005 & 0.006 \\
\hline 0.031 & 0.019 & 0.028 & 0.025 & 0.020 & 0.011 & 0.014 & & 0.014 & 0.006 & 0.049 & & 0.030 & 0.012 & 0.017 \\
\hline
\end{tabular}

Appendix 1: Bacteria count in hospital food service sample 1.

\begin{tabular}{|c|c|c|c|c|c|c|c|c|c|c|c|c|c|}
\hline \multicolumn{2}{|l|}{ Taxon } & S_BlastChiller_Wall & S_ColdStorage_Shelf & S_ColdStorage_Wall & K_Balance & $K \_$Sink & K. Workbench & PPF_Sink & PPF_Workbenc & PPR_Cutter & PPR_Sink & PPR_Workbench & PPV_CuttingBoard \\
\hline \multirow{2}{*}{\multicolumn{2}{|c|}{$\begin{array}{l}\text { Acinetobacter } \\
\text { Acinetobacter johnsonii }\end{array}$}} & 0.000 & 0.000 & 0.007 & 0.000 & 0.056 & 0.005 & 0.017 & 0.032 & 0.031 & 0.006 & 0.159 & 0.133 \\
\hline & & \multirow{2}{*}{$\begin{array}{l}0.001 \\
0.001\end{array}$} & 0.001 & 0.024 & 0.000 & 0.032 & 0.002 & 0.005 & 0.014 & 0.020 & 0.023 & 0.319 & $\begin{array}{l}0.133 \\
0.656\end{array}$ \\
\hline \multicolumn{2}{|c|}{ Alicyclobacillus } & & \multirow{2}{*}{$\begin{array}{l}0.004 \\
0.285\end{array}$} & 0.067 & 0.000 & 0.002 & 0.076 & 0.000 & 0.015 & 0.000 & 0.005 & \multirow{2}{*}{$\begin{array}{l}0.001 \\
0.000\end{array}$} & $\begin{array}{l}0.656 \\
0.000\end{array}$ \\
\hline \multirow{2}{*}{\multicolumn{2}{|c|}{$\begin{array}{l}\text { Brochothrix } \\
\text { Caulobacteraceae }\end{array}$}} & \multirow{2}{*}{$\begin{array}{l}0.002 \\
0.000\end{array}$} & & 0.013 & 0.024 & 0.000 & 0.005 & 0.000 & 0.003 & 0.004 & 0.030 & & 0.000 \\
\hline & & & 0.000 & 0.001 & 0.000 & 0.007 & 0.004 & 0.000 & 0.002 & 0.000 & 0.039 & 0.001 & 0.000 \\
\hline Chryseobacteri & & 0.000 & 0.000 & 0.004 & 0.000 & 0.053 & 0.000 & 0.036 & 0.034 & 0.002 & 0.039 & 0.020 & 0.000 \\
\hline Corynebacterit & & 0.000 & 0.001 & 0.012 & 0.000 & 0.000 & 0.016 & 0.000 & 0.001 & 0.023 & 0.000 & 0.007 & 0.000 \\
\hline Kocuria & & 0.009 & 0.002 & 0.158 & 0.000 & 0.004 & 0.015 & 0.488 & 0.006 & 0.068 & 0.230 & 0.003 & 0.000 \\
\hline Kocuria palust: & & 0.001 & 0.001 & 0.051 & 0.000 & 0.023 & 0.004 & 0.012 & 0.000 & 0.007 & 0.056 & 0.000 & 0.000 \\
\hline Massilia timon & & 0.001 & 0.000 & 0.002 & 0.000 & 0.008 & 0.033 & 0.061 & 0.032 & 0.001 & 0.097 & 0.008 & 0.009 \\
\hline Microbacteriut & & 0.000 & 0.000 & 0.006 & 0.000 & 0.005 & 0.001 & 0.000 & 0.029 & 0.000 & 0.022 & 0.001 & 0.000 \\
\hline Moraxellaceae & & 0.000 & 0.000 & 0.003 & 0.000 & 0.036 & 0.007 & 0.001 & 0.000 & 0.035 & 0.039 & 0.081 & 0.009 \\
\hline Paracoccus & & 0.000 & 0.000 & 0.057 & 0.000 & 0.007 & 0.042 & 0.042 & 0.209 & 0.018 & 0.054 & 0.023 & 0.000 \\
\hline Propionibacter & & 0.003 & 0.003 & 0.046 & 0.000 & 0.001 & 0.033 & 0.000 & 0.008 & 0.000 & 0.001 & 0.000 & 0.000 \\
\hline Pseudomonas & & 0.794 & 0.020 & 0.020 & 0.951 & 0.005 & 0.005 & 0.038 & 0.006 & 0.012 & 0.016 & 0.002 & 0.022 \\
\hline Psychrobacter & & 0.000 & 0.069 & 0.004 & 0.000 & 0.161 & 0.145 & 0.041 & 0.026 & 0.224 & 0.028 & 0.003 & 0.002 \\
\hline Rhodobacterac & & 0.000 & 0.000 & 0.006 & 0.000 & 0.002 & 0.000 & 0.000 & 0.015 & 0.000 & 0.016 & 0.023 & 0.001 \\
\hline Sphingobacteri & faecium & 0.000 & 0.000 & 0.000 & 0.000 & 0.008 & 0.000 & 0.058 & 0.037 & 0.002 & 0.000 & 0.000 & 0.000 \\
\hline Sphingomonas & & 0.003 & 0.000 & 0.002 & 0.000 & 0.001 & 0.000 & 0.001 & 0.056 & 0.000 & 0.004 & 0.001 & 0.000 \\
\hline Stenotrophomo & & 0.000 & 0.000 & 0.000 & 0.000 & 0.002 & 0.000 & 0.020 & 0.009 & 0.006 & 0.004 & 0.003 & 0.000 \\
\hline Other & & 0.035 & 0.007 & 0.048 & 0.005 & 0.044 & 0.028 & 0.026 & 0.023 & 0.040 & 0.034 & 0.035 & 0.015 \\
\hline PPV_Grinder & PPV_Sink & PPV_Workbench & PPW_Sink & PPW_Workbench & T_Colander & & uttingBoard & T_Knife & T_Pan & T_SteelDish & T_SteelPincers & T_SteelShovel & T_SteelTray \\
\hline 0.000 & 0.011 & 0.031 & 0.045 & 0.031 & 0.051 & 0.0 & & 0.017 & 0.001 & 0.087 & 0.003 & 0.044 & 0.004 \\
\hline 0.000 & 0.074 & 0.100 & 0.011 & 0.407 & 0.516 & 0.0 & & 0.001 & 0.007 & 0.535 & 0.009 & 0.545 & 0.058 \\
\hline 0.008 & 0.000 & 0.000 & 0.000 & 0.001 & 0.072 & 0.0 & & 0.000 & 0.015 & 0.004 & 0.091 & 0.008 & 0.006 \\
\hline 0.000 & 0.000 & 0.000 & 0.002 & 0.000 & 0.000 & 0.0 & & 0.000 & 0.000 & 0.000 & 0.000 & 0.001 & 0.004 \\
\hline 0.000 & 0.016 & 0.021 & 0.026 & 0.000 & 0.003 & 0.0 & & 0.000 & 0.001 & 0.000 & 0.000 & 0.000 & 0.000 \\
\hline 0.002 & 0.007 & 0.094 & 0.083 & 0.002 & 0.003 & 0.3 & & 0.081 & 0.000 & 0.163 & 0.001 & 0.002 & 0.003 \\
\hline 0.001 & 0.000 & 0.001 & 0.002 & 0.010 & 0.000 & 0.0 & & 0.001 & 0.001 & 0.000 & 0.028 & 0.002 & 0.001 \\
\hline 0.042 & 0.018 & 0.031 & 0.032 & 0.013 & 0.001 & 0.0 & & 0.008 & 0.010 & 0.002 & 0.070 & 0.001 & 0.012 \\
\hline 0.007 & 0.002 & 0.042 & 0.009 & 0.000 & 0.000 & 0.0 & & 0.001 & 0.002 & 0.000 & 0.006 & 0.000 & 0.000 \\
\hline 0.000 & 0.003 & 0.018 & 0.025 & 0.022 & 0.003 & 0.0 & & 0.299 & 0.000 & 0.000 & 0.003 & 0.001 & 0.010 \\
\hline 0.001 & 0.042 & 0.001 & 0.020 & 0.001 & 0.001 & 0.00 & & 0.000 & 0.000 & 0.000 & 0.002 & 0.000 & 0.000 \\
\hline 0.000 & 0.017 & 0.001 & 0.045 & 0.015 & 0.011 & 0.00 & & 0.001 & 0.005 & 0.002 & 0.011 & 0.007 & 0.003 \\
\hline 0.008 & 0.086 & 0.098 & 0.048 & 0.000 & 0.003 & 0.00 & & 0.050 & 0.008 & 0.000 & 0.007 & 0.001 & 0.000 \\
\hline $\begin{array}{l}0.001 \\
0.001\end{array}$ & 0.000 & 0.000 & 0.000 & 0.001 & 0.004 & 0.00 & & 0.000 & 0.203 & 0.001 & 0.010 & 0.002 & 0.001 \\
\hline 0.001 & 0.221 & 0.104 & 0.036 & 0.387 & 0.007 & 0.11 & & 0.024 & 0.004 & 0.072 & 0.010 & 0.002 & 0.001 \\
\hline 0.000 & 0.002 & 0.001 & 0.150 & 0.002 & 0.009 & 0.07 & & 0.190 & 0.295 & 0.000 & 0.004 & 0.006 & 0.391 \\
\hline 0.013 & 0.039 & 0.003 & 0.002 & 0.000 & 0.001 & $0.0 c$ & & 0.001 & 0.001 & 0.000 & 0.002 & 0.001 & 0.000 \\
\hline 0.000 & 0.000 & 0.000 & 0.019 & 0.000 & 0.001 & 0.08 & & 0.000 & 0.000 & 0.000 & 0.000 & 0.001 & 0.000 \\
\hline 0.003 & 0.020 & 0.012 & 0.012 & 0.000 & 0.000 & $0.0 c$ & & 0.000 & 0.000 & 0.000 & 0.006 & 0.000 & 0.000 \\
\hline 0.001 & 0.010 & 0.050 & 0.010 & 0.001 & 0.001 & 0.0 & & 0.004 & 0.000 & 0.000 & 0.000 & 0.001 & 0.000 \\
\hline 0.187 & 0.047 & 0.027 & 0.037 & 0.013 & 0.037 & 0.03 & & 0.034 & 0.044 & 0.011 & 0.133 & 0.047 & 0.025 \\
\hline
\end{tabular}

Appendix 2: Bacteria count in hospital service sample 2. 


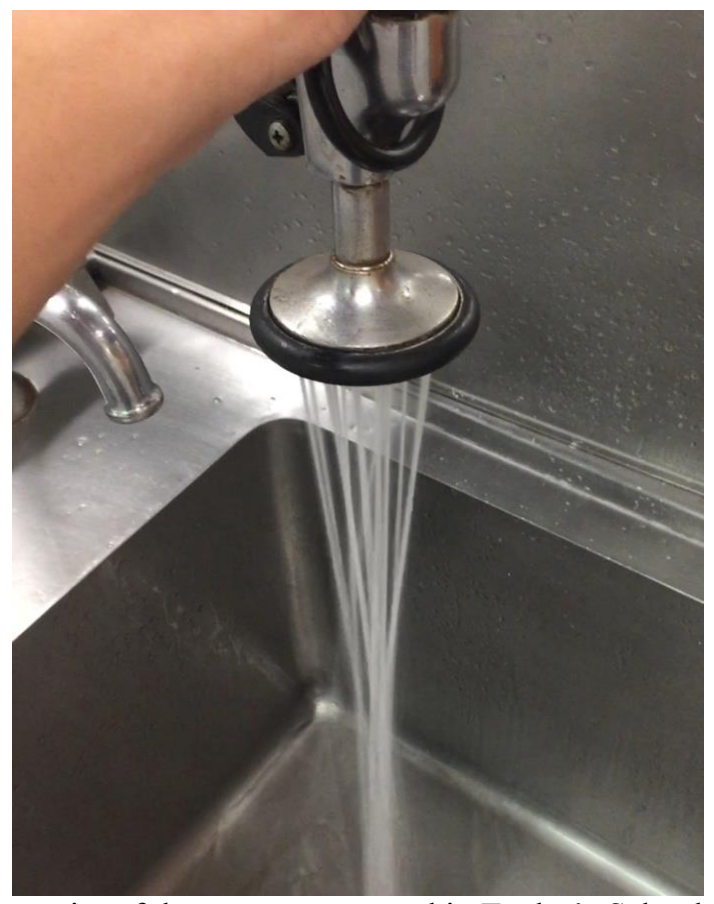

Appendix 3: Focus point of the water spray used in Taylor's School of Hospitality and Culinary Arts kitchen.

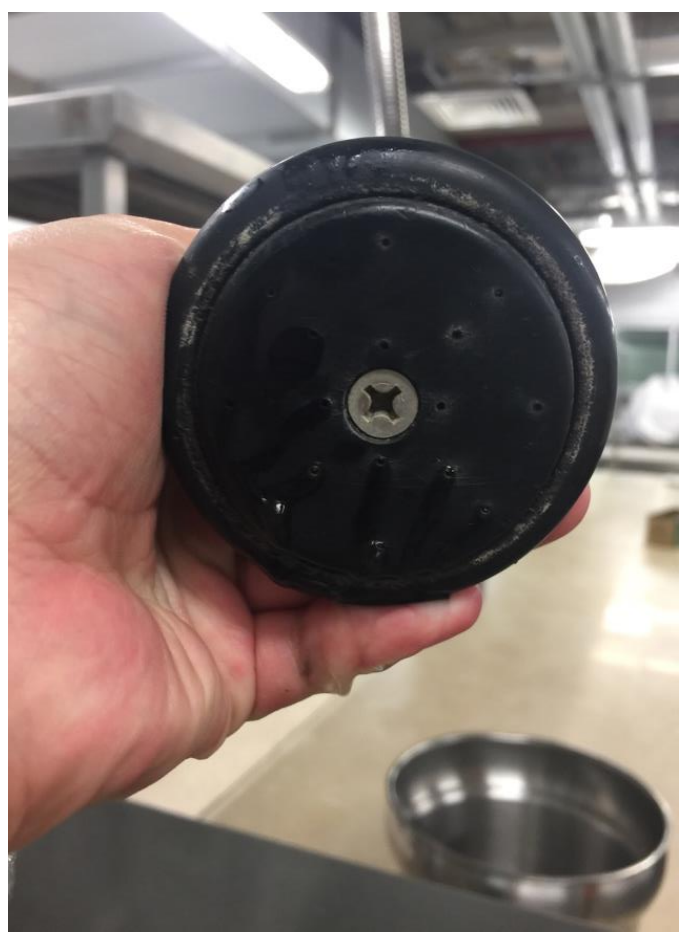

Appendix 4: Water spray profile. 